\title{
BİR ÖRNEK OLAY ÜZERİNDEN MAHKEME KARARLARINDA İSTIKRAR
}

\author{
Dr. Öğr. Üyesi Çınar Can EVREN*
}

\section{ÖZET}

Hukuk devleti ilkesi, Anayasa'nın 2. maddesinde yer alan cumhuriyetin niteliklerinden birisidir. Hukuk devleti ilkesi bir ideali ifade etmekte olup bu ilkenin hayata geçirilebilmesi, diğer gereklerin yanında hukuki güvenliğin sağlanmasını da gerektirir.

Devletin üç temel erki olan yasama, yürütme ve yargıya, bunların görevleriyle ilgili farklı farklı yükümlülükler getiren hukuki güvenlik ilkesi, "hukuki belirlilik", "hukuki istikrar" ve "hukuki öngörülebilirlik" alt ilkelerinden oluşur.

Hukukun yardımcı kaynaklarından olmakla birlikte özellikle idare hukukunun içtihadi bir hukuk dalı olması özelliği karşısında, yine bu hukuk dalında önemli bir yer tutan mahkeme kararlarında makul bir istikrar bulunması hukuki güvenlik ilkesinin bir gereğidir.

Farklı yargı düzenlerinde yer alan mahkemelerin, aynı yargı düzeni içinde yer alan farklı mahkemelerin ve aynı mahkemenin kararları arasında benzer konularda verilecek kararlar arasında makul bir istikrar bulunması gerekir. Yargısal düzeyde veya mahkeme düzeyinde bu istikrarın sağlanamaması, Anayasa Mahkemesi'nin pek çok bireysel başvuru kararında da ifade ettiği üzere, hakkın yerine getirilmesini engelleyeceği gibi hukuki güvenlik ilkesine ve adil yargılanma hakkının ihlaline neden olabilir.

Bu makalede istikrar ilkesi, Danıştay'ın aynı dairesinin aynı gün ve aynı olaya ilişkin verdiği iki farklı kararı göz önünde bulundurularak incelenecektir.

Anahtar Kelimeler: Yargı Kararlarında İstikrar, Hukuki Güvenlik İlkesi, Adil Yargılanma Hakkı, Anayasa Mahkemesi, Danıştay.

Ankara Hacı Bayram Veli Üniversitesi, Hukuk Fakültesi, İdare Hukuku Anabilim Dalı, ccevren@hotmail.com, ORCID ID : 0000-0003-3685-5046,

(Geliş Tarihi: 07.05.2019 - Kabul Tarihi: 21.06.20196) 


\title{
CONSISTENCY OF COURT DECISIONS THROUGH A CASE STUDY
}

\begin{abstract}
The principle of the rule of law is one of the main components of the republic, which is included in Article 2 of the Constitution. The principle of the rule of law refers to an ideal, and the realization of this principle requires the provision of legal security as well as other requirements.

The principle of legal security which imposes different obligations on three main bodies of the state, consists of three sub-principles including legal certainty, legal consistency and legal predictability.

Being one of the auxiliary sources of law, especially in the field of administrative law, reasonable stability in the case law must be accomplished as a requirement of the principle of legal security.

There should be a reasonable level of consistency among the decisions of courts in different jurisdictions, the decisions of different courts in the same jurisdiction and the decisions of the very same court on similar cases. The failure to achieve such consistency at the judicial or court level, as stated by the Constitutional Court in its decisions regarding many individual applications, may prevent the fulfillment of rights and may lead to a breach of the principle of legal certainty and the right to a fair trial.

In this article consistency principle will be examined by considering The Council of State's two different judicial decisions which were given by the same chamber, on the same date and about the same subject.
\end{abstract}

Key words: Consistency in Court Decisions, Principle of Legal Certainty, The Right to A Fair Trial, Constitutional Court, Council of State. 


\section{GİRIŞ}

Bu makalenin amacı, mahkeme kararlarında "makul bir istikrar" bulunması gereğine vurgu yapmaktır. Konu, hak arama hürriyeti, adil yargılanma hakkı ve hukuki güvenlik ilkesi ile bağlantılı olarak anlatılacak ve bu arada Danıştay 10. Dairesi'nin iki kararına ayrıca değinilecektir.

İlk derece mahkemeleri ve yüksek mahkemelerin pek çok çelişkili, hakkın yerine getirilmesine engel olabilecek kararı olmakla birlikte özellikle bu iki kararın seçilmesinin nedeni, tespit edebildiğimiz kadarıyla, yayımlanmamış olması ve daha da önemlisi mahkeme kararlarında istikrarsızlık haline güzel bir örnek teşkil etmesidir. Şöyle ki aynı konuda aynı idare tarafından tesis edilmiş ve işlemin muhatapları aynı olan iki işlemden biri Danıştay 10. Dairesi tarafından hukuka aykırı bulunurken ikinci işlem aynı Dairenin aynı tetkik hâkiminin hazırladığı rapor üzerine aynı heyet tarafından ve aynı tarihte dava reddedilmek suretiyle hukuka uygun bulunmuştur.

\section{I. ÖRNEK OLAY VE MAHKEME KARARLARI}

Gazi Üniversitesine (Üniversite) tahsisli ancak devredilmediği için fiilen Üniversite tarafından kullanılamayan taşınmaza ilişkin olarak (işlem tarihinde) Maliye Bakanlığınca 178 sayılı Maliye Bakanlığının Teşkilat ve Görevleri Hakkında Kanun Hükmünde Kararname'nin 13. maddesine uyarınca Üniversite adına olan tahsisin kaldırılması ve söz konusu taşınmazın Milli Eğitim Bakanlığı (Bakanlık) adına tahsisine karar verilmiştir (03.11.2004 tarih ve 38263 sayılı ilk tahsis işlemi).

İlk tahsis işleminin gerekçesi; taşınmazın halen Bakanlıkça kullanıldığı, taşınmazın hizmete uygun onarım yapılması nedeniyle derslik, laboratuvar ve yurt binası özelliklerini kaybettiği ve Bakanlığın bu taşınmaza ihtiyacı bulunduğudur.

İlk tahsis işlemine karşı Üniversitenin açtığı iptal davası Ankara 6. İdare Mahkemesince şu gerekçelerle reddedilmiştir: "1990 yılında Gazi Üniversitesine tahsis edilmekle birlikte bu taşınmazın 1962 yılından itibaren fiilen Milli Eğitim Bakanlı̆̆ınca kullanılması ve hizmete uygun onarım ve tadilat yapılması dolayısıyla Gazi Üniversitesince tahsis amacına uygun olarak kullanılmaması nedeniyle davalı idarece .... tanınan yetki çerçevesinde kamu yararı ve hizmet gerek- 
leri gözetilmek suretiyle taşınmazın tahsisinin değiştirilerek Milli Eğitim Bakanlığına tahsisinde hukuka aykırılık bulunmamaktadır." (17.01.2008 tarih, E. 2004/3372, K. 2008/46 sayılı karar)

Ankara 6. İdare Mahkemesi'nin 17.01.2008 tarihli kararının temyizi üzerine Danıştay 10. Dairesi, “... Maliye Bakanlığının, tahsis işlemini yaparken ihtiyaç değerlendirmesi yaptığı ve bunun sonucuna göre tahsis işlemini gerçekleştirdiği kuşkusuzdur. Söz konusu değerlendirmenin tahsisin kaldırlması ve veya taşınmazın başka bir idareye tahsisinin söz konusu olduğu durumlarda da yapılacağı tabidir. Dolayısıyla bir kamu kuruluşuna yapılan tahsis amacının ortadan kalktığı veya bu amacın gerçekleştirilmesinin olanaksız hale geldiği saptanmadiğı sürece tahsisin kaldırılamayacağı açıktır. ... İnceleme konusu olayda davacı Gazi Üniversitesi Rektörlüğünün, 1990 yılında, yüksek öğretmen okulu olarak kendisine tahsis edilen taşınmazı fiilen kullanmadiğı ve/veya kullanamadiğı sabittir. Ancak 1990 yılında mahallinde düzenlenen 1.2.1990 tarihli tutanak ile fiili durumu tespit edilen taşınmazın, tahsis amacı da belirtilmek suretiyle Gazi Üniversitesi Rektörlü̆̈̈̈ adına mevzuata uygun bir şekilde tahsis edildiği ve bu tarih itibariyle ortada hukuki geçerliliği tartı̧̧masız bir tahsis işleminin var olduğu şüphesizdir. ... Bakılan uyuşmazlıkta, Davacı Üniversiteye tahsisi yapılan taşınmazın konumu itibariyle Üniversitenin merkez kampüsü ile diğer fakültelerinin yoğun olarak bulunduğu alanda yer aldiğı, eğitim hizmetlerinin birlikte yürütülmesi isteğinden hareketle söz konusu taşınmaza anılan Üniversitenin ihtiyacının bulunduğu ve bu bağlamda Üniversiteye yapılan tahsis amacının ortadan kalkmadiğı ve bu amaca yönelik hizmetin gerçekleştirilmesinin ise olanaklı olduğu açıkça görülmektedir. Bu itibarla, söz konusu taşınmazın Gazi Üniversitesi Rektörlüğüme yapılan tahsis amacının varlığını koruması karşısında; tahsis işlemi yapmaya ve kaldırmaya yetkili Maliye Bakanlı̆̆ının davacı Üniversiteye tahsis işlemi yapıldıktan sonra her iki kamu idaresinin de ihtiyaçlarında ne gibi bir değişiklik olduğunu değerlendirmesi ve ... bu taşınmaza hangi idarenin daha fazla ihtiyacı bulunduğunu somut verilerle ortaya koyarak devir konusunda bir karar vermesi gerekmektedir." gerekçesiyle kararı bozmuştur. (23.05.2012 tarih, E: 2008/11811, K. 2012/2444 sayılı karar)

Bu karara karşı yapılan karar düzeltme başvurusu da reddedilmiştir (27.02.2014 tarih, E. 2012/6293, K. 2014/1228 sayılı karar) Danıştay 10. Dairesi karar düzeltme isteminin reddine karar verirken, karar düzeltme gerekçelerinin gerçekleşmediğini ifade etmekle yetinmiştir. 
Danıştay 10. Dairesi'nin 23.05.2012 tarihli bozma kararı sonrası Ankara 6. İdare Mahkemesi bozma kararı doğrultusunda şu şekilde hüküm kurmuştur: “... Maliye Bakanlı̆̆ının, tahsis işlemini yaparken ihtiyaç değerlendirmesi yaptığı ve bunun sonucuna göre tahsis işlemini gerçekleştirdiği kuşkusuzdur. Söz konusu değerlendirmenin tahsisin kaldırılması ve/veya taşınmazın başka bir idareye tahsisinin söz konusu olduğu durumlarda da yapılacă̆ı tabidir. Dolayısıyla bir kamu kuruluşuna yapılan tahsis amacının ortadan kalktığı veya bu amacın gerçekleştirilmesinin olanaksız hale geldiği saptanmadığı sürece tahsisin kaldırılamayacă̆ı açıktır. Zira, tahsis amacının varlığını sürdürdüğ̈̈ ve bu amaca yönelik hizmetlerin gerçekleştirilmesinin olanaklı olduğu durumlarda tahsisin kaldırılması, ...kamu hizmeti gereklerine aykırı düssecektir. ... İnceleme konusu olayda davacı Gazi Üniversitesi Rektörlüğ̈̈nün, 1990 yılında, yüksek öğretmen okulu olarak kendisine tahsis edilen taşınmazı fiilen kullanmadı̆̆ 1 ve/veya kullanamadiğı sabittir. Ancak 1990 yılında mahallinde düzenlenen 1.2.1990 tarihli tutanak ile fiili durumu tespit edilen taşınmazın, tahsis amacı da belirtilmek suretiyle Gazi Üniversitesi Rektörlüğ̈̈ adına mevzuata uygun bir şekilde tahsis edildiği ve bu tarih itibariyle ortada hukuki geçerliliği tartışmasız bir tahsis işleminin var olduğu şüphesizdir. Bakılan uyuşmazlıkta, Davacı Üniversiteye tahsisi yapılan taşınmazın konumu itibariyle Üniversitenin merkez kampüsü ile diğer fakültelerinin yoğun olarak bulunduğu alanda yer aldı̆̆ lerinin birlikte yürütü̈lmesi isteğinden hareketle söz konusu taşınmaza anılan Üniversitenin ihtiyacının bulunduğu ve bu bağlamda Üniversiteye yapılan tahsis amacının ortadan kalkmadiğı ve bu amaca yönelik hizmetin gerçekleştirilmesinin ise olanaklı olduğu açıkça görülmektedir. Bu itibarla, söz konusu taşınmazın Gazi Üniversitesi Rektörlü̈̆̈̈̈ne yapılan tahsis amacının varlı̆̆ını koruması karşısında; tahsis işlemi yapmaya ve kaldırmaya yetkili Maliye Bakanlı̆̆ının davacı Üniversiteye tahsislerini yapıldıktan sonra her iki kamu idaresinin de ihtiyaçlarında ne gibi bir değişiklik olduğunu değerlendirmesi ve ... bu taşınmaza hangi idarenin daha fazla ihtiyacı bulunduğunu somut verilerle ortaya koyarak devir konusunda bir karar vermesi gerekmektedir. Buna göre davalı idarenin anılan hususları dikkate almadan tesis ettiği dava konusu işlemde hukuka uyarlık bulunmamaktadır." (11.09.2014 tarih, E. 2014/716, K. 2014/928 say1l karar) 
Ankara 6. İdare Mahkemesi'nin 11.09.2014 tarihli kararı Danıştay 10. Dairesi'nin 12.02.2016 tarih, E. 2015/305, K. 2016/736 sayılı kararı ile onanmış ve bu karara karşı yapılan karar düzeltme başvurusu da yine aynı Daire tarafından 10.10.2017 tarih, E. 2016/3782, K. 2017/4037 sayılı karar ile reddedilmiştir (ilk karar). Danıştay 10. Dairesi temyiz ve karar düzeltme kararlarında temyiz ve karar düzeltme şartlarının sağlanmadığını ifade etmekle yetinmiştir.

İlk tahsis işlemine karşı açılan davada yargılama devam ederken Maliye Bakanlığg 29.05.2015 tarihinde 13569 sayılı yeni bir karar almıştır (ikinci tahsis işlemi). İkinci tahsis işlemiyle de yine, taşınmazın Üniversiteye olan tahsisi kaldırılmış ve Bakanlık adına tahsis yapılmıştır. İkinci tahsis işleminin gerekçesi ise şöyledir: "Milli Ĕgitim Bakanliğından alınan 05/5/2015 tarihli ve 4684338 sayıl yazıda; 29/9/2003 tarihli ve 8407 sayıl yazılarında sözü edilen hususlar yenilenerek, Bakanlıklarının birçok hizmet biriminin bulunduğu ve 1000'e yakın kişinin istihdam edildiği anılan taşınmazın Bakanlıkları hizmetlerinde kullanılmak üzere yeniden tahsisi talep edilmiştir. Bunun üzerine Ankara Valiliğine gönderilen 13/5/2015 tarihli ve 12069 sayıl yazımızda; konu ile ilgili Bakanlığımızca yapılacak işleme esas olmak üzere, anılan taşınmazın ne kadarlık kısmının hangi idare tarafından ve hangi amaçlarla, hangi tarihten beri kullanıldığının adları ile birlikte renkli olarak kroki üzerinde işaretlenerek Bakanlığımıza gönderilmesi istenilmiş olup, cevaben alınan 26/5/2015 tarihli ve 38512 sayılı yazı eki liste ve krokide; söz konusu taşınmazın tamamının Milli Ĕ̆itim Bakanlı̆̆ı tarafından kullanıldı̆̆ belirtilmiştir. Yukarıda detayları ile açıklanan konu hakkında; Danıştay 10. Dairesinin 23/5/2012 tarihli E: 2008/111811, K. 2012/2444 sayıl ilamında yer alan "söz konusu taşınmazın Gazi Üniversitesi Rektörlü̈̆̈̈ne yapılan tahsis amacının varlı̆̆ın koruması karşısında; tahsis işlemi yapmaya ve kaldırmaya yetkili Maliye Bakanlığının davacı Üniversiteye tahsis işlemi yapıldıktan sonra her iki kamu idaresinin de ihtiyaçlarında ne gibi bir değişiklik olduğunu değerlendirmesi ve yukarıda belirtilen hususları da dikkate almak suretiyle, bu taşınmaza hangi idarenin daha fazla ihtiyacı bulunduğunu somut verilerle ortaya koyarak devir konusunda bir karar vermesi gerekmektedir." hususu ile ... Yüksek Öğretmen Okulu olarak kullanılmak üzere Gazi Üniversitesi Rektörlüğ̈̈ne tahsis işleminin yapılmasına rağmen, bu tarihten önce 1978 yılımda Yüksek Öğretmen Okulu kapandiğında yer tesliminin yapılmaması, Anılan taşınmazın evveliyat (1962 yılı) itibariyle Milli Eğitim Bakanlı̆̆ına tahsisli iken görüş alınmadan hatalı olarak düzenlenen 01/02/1990 ta- 
rihli tutanak esas alınarak, adı geçen Üniversiteye tahsisinin yapılması, taşınmazın bugüne kadar aralıksız olarak Milli Ĕ̆itim Bakanlığınca Bakanlık hizmetlerinde kullanılması ve Gazi Üniversitesinin herhangi bir kullanımının bulunmaması hususları birlikte değerlendirildiğinde .... Gazi Üniversitesi Rektörlüğ̈̈ adına olan tahsisinin kaldırılarak, Bakanlık hizmetlerinde kullanılmak üzere, Milli Eğitim bakanlığına tahsis edilmesi uygun görülmüştür.”

Maliye Bakanlığı'nın 29.05.2015 tarihli ikinci tahsis işlemine karşı da dava açılmıştır. Ankara 8. İdare Mahkemesi; “... Maliye Bakanlığının, tahsis işlemini yaparken ihtiyaç değerlendirmesi yaptı̆̆ı ve bunun sonucuna göre tahsis işlemini gerçekleştirdiği kuşkusuzdur. Söz konusu değerlendirmenin tahsisin kaldırılması ve veya taşınmazın başka bir idareye tahsisinin söz konusu olduğu durumlarda da yapılacağı tabidir. Dolayısıyla bir kamu kuruluşuna yapılan tahsis amacının ortadan kalktığı veya bu amacın gerçekleştirilmesinin olanaksız hale geldiği saptanmadiğı sürece tahsisin kaldırılamayacağı açıktır. Zira, tahsis amacının varlığını sürdürdü̈̆̈̈ ve bu amaca yönelik hizmetlerin gerçekleştirilmesinin olanaklı olduğu durumlarda tahsisin kaldırlması, ... kamu hizmeti gereklerine aykırı düşecektir. ... Dava konusu uyuşmazlıkta, dosyada yer alan bilgi ve belgeler ile mevzuatın birlikte değerlendirilmesinden, dava konusu taşınmazın 1962 yılından bu yana halen Milli Ĕ̆itim Bakanlı̆̆ı uhdesinde olduğu, Gazi Üniversitesi Rektörlü̈̆̈̈̈nün, 1990 yılında, yüksek öğretmen okulu olarak kullanılmak üzere kendisine tahsis edilen taşınmazı fiilen kullanmadiğı, söz konusu taşınmaza Milli Eğitim Bakanliğının ihtiyacının bulunduğu, bu hususun yapılan tespitle de sabit olduğu, bu bağlamda Üniversiteye yapılan tahsis amacının ortadan kalktığı kanaatine varılmakla, ... dava konusu işlemde hukuka aykırılık görülmemiştir.” gerekçesiyle davanın reddine karar vermiştir. (11.07.2016 tarih, E. 2015/1807, K. 2016/2158 say1l karar)

Ankara 8. İdare Mahkemesi'nin 11.07.2016 tarihli kararı temyiz edilmiş; Danıştay 10. Dairesi 10.10.2017 tarih, E. 2017/1172, K. 2017/4038 sayılı kararı ile temyiz istemini reddetmiştir ${ }^{2}$ (ikinci karar). Danıştay 10. Dairesi temyiz istemini reddettiği kararında "temyizen incelenene karar usul ve hukuka uygun olup, dilekçede ileri sürülen temyiz nedenleri kararın bozulmasını gerektirecek nitelikte görülmediğinden temyiz isteminin reddine” şeklinde bir gerekçe kullanmiştır

Bu karara karşı da karar düzeltme başvurusu yapılmış olup makale hazırlanırken henüz bir karar gelmemiştir. 


\section{MAHKEME KARARLARININ HUKUKİ İŞLEVI}

Mahkeme kararı, "yargı organının, önüne gelen bir uyuşmazlığı kesin olarak çözmek amacıyla, uyuşmazlığa ilişkin kişiler ve olaylar ile somut hukuki durumlara ilişkin araştırma, gözlem ve hukukun ne dediğini belirlemek faaliyetinin sonucu olarak, hâkimin vicdani kanaati ile vardiğı sonucu, yazılı hüküm olarak tespit ettiği kararlar" şeklinde tanımlanmaktadır³.

Mahkeme kararları, bir konuda hukuki çözüm bulunmasında yol gösterici, aydınlatıcı nitelikte ${ }^{4}$ olup hukukun yardımcı kaynaklarındandır. Mahkeme kararlarının yardımcı kaynak olması nedeniyle bir mahkemenin kararı, o kararı veren mahkemeyi, diğer mahkemeleri ve kararın muhatabı olmayan diğer idareleri, kural olarak, bağlamaz 5 . Kararın muhatabı olan idare Anayasa ve İdari Yargılama Usulü Kanunu hükümleri uyarınca yargı kararına uymakla yükümlü olmakla birlikte, pozitif hukuk açısından kararı veren mahkemenin benzer bir olayda aynı yönde bir karar verme yükümlülüğü bulunmamaktadır. Nitekim Anayasa'nın 138. maddesine göre "Yasama ve yürütme organları ile idare, mahkeme kararlarına uymak zorundadır; bu organlar ve idare, mahkeme kararların hiçbir suretle değiştiremez ve bunların yerine getirilmesini geciktiremez."6. Danıştay'a ${ }^{7}$ göre de “...yüksek mahkemelerin içtihatları birleştirme kararları yargı organlarını bağladığı gibi, idareyi de bağlayan kararlardır. İdare, benzeri olaylarda bu kararlar yönünde işlem tesisine zorunlu bulunmaktadır. Bunun dışındaki kesin yargı kararları ise, yalnızca tarafları bağlayan kararlardır."

Mahkeme kararlarının hukukun yarımcı kaynağı olduğu, mevzuatta da açıkça düzenlenmiştir. 4721 s. Türk Medeni Kanunu madde 1/3'e göre "Hâkim, karar verirken bilimsel görüşlerden ve yargı kararlarından yararlanır.”

3 Akyılmaz, Bahtiyar/Sezginer, Murat/Kaya, Cemil (2019) Türk İdare Hukuku, 10. Baskı, Ankara, Savaş Yayınevi, s. 49.

4 Giritli, İsmet/Bilgen, Pertev/Akgüner, Tayfun/Berk, Kahraman (2013) İdare Hukuku, İstanbul, Der Yayınları, s. 182.

5 Akyılmaz/Sezginer/Kaya, s. 49; Gözübüyük, Şeref/Tan, Turgut (2013) İdare Hukuku Cilt I Genel Esaslar, 9. Bas1, Ankara, Turhan Kitabevi, s. 135.

6 İçtihatları birleştirme kararları ve Anayasa Mahkemesi kararları (m. 153/son) bu genel kuralın istisnalarıdır.

7 D1D, E. 1996/172, K. 1996/190, KT. 30.09.1996, DD, 1997, s. 92, s. 83, aktaran, Akyılmaz/Sezginer/Kaya, s. 50. 
Mahkeme kararları her ne kadar hukukun yardımcı kaynaklarından olsa da uygulamada son derece önemli bir yere sahiptir. Mahkemeler karar verirken önceki kararlardan yararlandıkları gibi, taraflar da iddialarını ve savunmalarını hazırlarken benzer konulardaki mahkeme kararlarını dilekçelerine eklemektedirler ${ }^{8}$. Doktrinde de "idare hukukunda yargısal içtihatların çoğu kez Anayasadan hemen sonra gel"diğini ifade edenler bulunmaktadır'.

\section{MAHKEMELERIN BENZER OLAYLARDA FARKLI KARAR- LAR VERMESINIIN (İÇTIHAT İSTIKRARSIZLIĞININ) MUHTEMEL GEREKÇELERİ}

Dava sayısı karşısında içtihat takibinin zorluğu; aynı konuda görevli birden fazla daire ve daire içinde heyet bulunması ve bunlar arasında koordinasyonu sağlayacak mekanizmaların bulunmaması; mahkemelerinin görevlerinin, hâkimlerin ve heyet üyelerinin sık sık değişmesi, benzer olaylarda farklı kararlar verilmesinin sebeplerindendir. Bunların yanında iş yoğunluğu karşısında mahkemelerin detaylı bir biçimde eski kararlarını araştıramaması; mevzuatın ${ }^{10}$ yeni

8 "Hukuk Fakültesini yeni bitirmiş çiçeği burnunda bir hukukçu, fakültede aldiğı klasik hukuk eğitiminin etkisiyle, hukukun yaz ılı kaynaklarının Anayasa, Uluslararası sözleşmeler, kanun, tüzük ve yönetmelikler olduğu ve bu kaynaklar arasında hiyerarşik bir ilişki olduğu, düşüncesindedir. 0, Içtihadı Birleştirme Kararlarının da kanun gereği bağlayıcı olması nedeniyle, hukukun asli kaynaklarından sayılabileceğini, ancak genel olarak, yargısal içtihatların hukukun asil kaynaklarından sayılmadığını öğrenmiştir. Bu genç hukukçu, uygulamaya atıldı̆̆ında, klasik hukuk öğretisinin normlar hiyerarşisi teorisinin, realitede, tam tersi bir yapılanma gösterdiğini; tatbikatta, yargısal içtihatların normlar hiyerarşisinin tepesine gelip oturduğunu, hatta bir davanın kaderini konuyla ilgili yasa maddesinden daha fazla etkilediğini, hayretle müşahede eder." Kayhan, Fahrettin (1999) "Özel Hukuk Uygulamasında Yargı İçtihatlarının ve İçtihadı Birleştirme Kararlarının Normatif Gücü”, Türkiye Barolar Birliği Dergisi, S: 2, s. 341.

9 Günday, Metin (2013) İdare Hukuku, 10. Baskı, Ankara, s. 33.

10 “...hukukta nesnelliğin sağlanabilmesi açısından hukuk kurallarının belli ölçüde soyut kavramlar içermesi kaçınılmazdır. Nesnel hukuk kurallarının maddi alemde gerçekleşen olaylarla birebir örtüşmesi ve bunlara uygulanması ise her zaman mümkün olamayabilmektedir. Öte yandan hukuk kurallarının kapsamının tespitinde kural koyucu ne kadar titiz davranırsa davransin kuralın yürürlüğe girmesinden ve uygulanmaya başlamasından sonra önceden öngörülemeyen bazı yeni durumların ortaya çıkması da mümkündür. Bu gibi hallerde kuralın yetkili otoritelerce ve özellikle yargı organlarınca yorumlanması zorunlu hale gelmektedir. Kuralı yo- 
olması, sık değişmesi veya muğlaklığı nedeniyle farklı yorumlara açık olması; mahkemelerin aynı mahiyetteki davalarda uyuşmazlığın çözümü için gerekli olan bir yasa hükmünü uygularken, bir hukuki müesseseyi değerlendirirken ya da uyuşmazlığın çözümünde takip edilecek usulü belirlerken birbirinden farklı ilke ve yorumlar benimsemesi ${ }^{11}$ ve davanın taraflarının önceki kararları konusunda mahkemeleri uyarmaması da içtihat farklılıklarına yol açan sebeplerdendir.

Yargılama faaliyeti soyut normun anlamını araştırmak, yorumlamak ve bunu yaparken de somut olayın özelliklerini göz önünde bulundurmayı gerektirir. Özellikle idare hukuku açısından mahkemenin benzer konularda farklı kararlar vermesinin belki de en önemli sebebi budur.

Benzer konularda farklı kararlar verilebilmesinin Anayasa'da da zımnen kabul edildiği söylenebilir. Anayasa madde 138/1'de hâkimlerin “Anayasaya, kanuna ve hukuka uygun olarak vicdanı kanaatlerine göre hüküm ver(ecekleri)" belirtilmiştir. Her somut olayda adaletin, hâkimin veya mahkeme heyetinin vicdani kanaatine göre, önceki olaydakiyle benzer özellik gösterse bile farklı tezahür etmesi mümkündür. Ancak bu durumda yine anayasal bir kural olan gerekçe ilkesinin doğru bir biçimde işletilmesi gerekir ${ }^{12}$.

\section{MAHKEME KARARLARINDA İSTIKKRAR SAĞLANMASI}

Mahkeme kararlarında istikrarın sağlanması gerekliliği anlatılırken öncelikle, mahkeme kararlarında bulunması gereken istikrarın düzeyi (makul istikrar); istikrarın sağlanmasının yararları ve sağlanamamasının doğuracağı sakıncalar ve hangi hallerde mahkemenin benzer olaylarda farklı kararlar verebileceği üzerinde durulmalıdır.

rumlayan otoritelerin birden fazla olması, bazı hallerde kuralın birden fazla yorumunu önlenemez kılmaktadır.” AyM İkinci Bölüm: Mehmet Arif Madenci Başvurusu/Başvuru No. 2014/13916, par. 84.

11 AyM İkinci Bölüm: Engin Selek Başvurusu/Başvuru No. 2015/19816, par. 54.

12 Anayasa m. 141/3: “Bütün mahkemelerin her türlü kararları gerekçeli olarak yazılır.” Bu kural özellikle mahkemenin benzer konularda farklı karar vereceği veya istikrar kazanmış bir içtihadını değiştireceği hallerde daha da önem kazanır. 


\section{A. MAKUL ÍSTIKKRAR}

Mahkeme kararlarında istikrar, "mahkemelerin önceki kararlarında vermiş olduğu hükümlerle tutarlı kararlar vermesi” olarak tarif edilebilir ${ }^{13}$. Ancak istikrarın mahkemenin önceden vermiş olduğu bir karardaki hükümle tamamıla aynı olması gerekmeyip, "makul" bir istikrar yeterlidir ${ }^{14}$. Anayasa Mahkemesi'ne ${ }^{15}$ göre "Yargısal kararlardaki değişiklikler, hukukun dinamizmini ve mahkemelerin yaklaşımlarını yaşanan gelişmelere uyarlama kabiliyetlerini yansıtması yönüyle olumludur." Diğer bir deyişle mahkeme kararlarının değişmezliği söz konusu değildir.

Makul istikrar çeşitli nedenlere bağlı olarak farklı kararlar verilebilmesini mümkün kılar. Örneğin sosyal şartlar ve ilişkilerdeki değişiklikler her zaman için eski uygulamaları izlemeye imkân vermez ${ }^{16}$. Anayasa Mahkemesi'ne göre hukuki güvenlik ve belirlilik kavramı, mahkeme kararlarında makul bir istikrarın sağlanması hususu ile doğrudan ilgilidir. Yargı makamlarının benzer davalarda daha önceki kararlarıyla kabul edilebilir oranlarda uyumlu kararlar vermesi gerekir. Mahkeme kararlarında istikrarlı değerlendirmelerin dışındaki bir yaklaşımın hukukun dinamik yorumuyla uyumlu ve gelişmeye yönelik olarak verildiğinin yeterli ve makul gerekçeyle açıklanması gerekir ${ }^{17}$.

\section{B. İSTIKKRAR SAĞLAMANIN YARARLARI VE SAĞLANAMAMA- SININ SAKINCALARI}

Mahkeme kararlarında istikrar sağlanması; eşitlik, adalet ve hukuki güvenlik ilkelerinin gereğidir.

13 Mahkeme kararlarında veya mahkeme düzeyinde istikrar yargı düzeyinde istikrardan farklı olup ikincisi "mahkemelerin kararlarının üst denetim mercilerinin kararlarıla ve diğer mahkemelerin kararlarıyla tutarlı olmasıdır." Köküsarı, İsmail (2015) Anayasa Hukukunda Hukuki Güvenlik İlkesi, Ankara, Adalet Yayınevi, s. 116 ve 117.

14 Makul istikrar, mahkemelerin; önceki kararlarından tamamıla bağımsız ve keyfi bir şekilde karar vermemesi ve önceki kararlarıyla tamamıla aynı kararı vermek zorunda da olmaması şeklinde anlaşılmaktadır. Köküssarı, s. 116.

15 AyM İkinci Bölüm: Ercan Din Başvurusu/Başvuru No. 2014/94, par. 59.

16 Güriz, Adnan (2003) Hukuk Başlangıc1, 9. Baskı, Ankara, Siyasal Kitabevi, s. 65.

17 AyM İkinci Bölüm: Ahmet Acar Başvurusu/Başvuru No. 2014/19936, par. 58. Ayrıca bkz. AyM İkinci Bölüm: Faruk Büyük Başvurusu/Başvuru No. 2015/17044, par. 40; AyM İkinci Bölüm: Burak Bulut ve Diğerleri Başvurusu/Başvuru No. 2015/17344, par. 47. 
Mahkeme kararlarında istikrar olması çeşitli yararlar sağlar. Bu cümleden olmak üzere; içtihatların yerleşik ve herkesçe bilinir olması (idari veya yargısal) yapılacak başvuruların azalmasına imkân verir. Yargıya güven korunur ve $\operatorname{artar}^{18}$. Birbirine zit kararlar verilmemesi sayesinde adalet ve hakkaniyet sağlanır ${ }^{19}$. Kanun yolları başvurularının azaltılmasına yardımcı olur.

Önceki kararlardan yararlanma ${ }^{20}$ mahkemenin önündeki uyuşmazlık için vereceği kararda zaman ve emekten tasarruf etmesini, kararın sorumluluğunu tek başına üstlenmekten kurtulmasını ve mahkeme kararlarında birlik ve uyumu sağlar ${ }^{21}$.

Benzer davaların benzer şekilde çözümlenmesi hukuk hayatında eşitlik, kesinlik, tarafsızlık ve hukuki belirlilik ilkelerinin de gerçekleştirilmesinde yardımcı olur ${ }^{22}$. Kararlar arasında istikrar sağlanması özellikle içtihat mahkemesi konumunda olan yüksek mahkemeler için önemlidirr ${ }^{23}$. Anayasa Mahkemesi'ne ${ }^{24}$ göre "farklı uygulamaların yüksek mahkemeler nezdinde gelişmesi durumunda, toplumun yargiya güvenini azaltacak nitelikte bir hukuki belirsizliğin oluşmasına izin verilmemelidir. Böyle bir durumda, adli makamların -özen yükümlülükleri gereği-farklı uygulamaları ortadan kaldırmaya yönelik usule ilişkin güvenceleri devreye sokmaları beklenir. İlgili adli makamlar, adil yargılanma hakkının da içeriğine dahil olan hukuki güvenlik ilkesini ihlal ederek hukuki belirsizliğin bizatihi kaynă̆ı olmamalıdır.”

18 "Yargı mercilerinin ... kamuoyu nezdinde yargıya olan güveni muhafaza etme bakımından kararlarında belli bir istikrar sağlaması beklenir.” AyM Genel Kurul: Hakan Altıncan Başvurusu/Başvuru No. 2016/13021, par. 48.

19 Duran, Lütfi "Yüksek Mahkemeler Arasında İçtihat Uyuşmazlı̆̆g”, Mukayeseli Hukuk Araştırmaları Dergisi, Cezaevi Matbaası, İstanbul 1967, http://dergipark.gov.tr/download/articlefile/ 14133, s. 9 .

20 Mahkeme kararları bir kanun hükmünün (soyut) somut olaya nasıl uygulandığını göstermesi açısından önemli olup bir kanun hükmünün nasıl anlaşıldığı, nasıl uygulandığ 1 konusunda bir mahkeme daha önce verilmiş kararları incelemelidir. Bu noktada özellikle içtihat mahkemesi niteliğindeki yüksek mahkemelerin kararları önemlidir. Bilge, Necip (2010) Hukuk Başlangıc1, 28. Bası, Ankara, Turhan Kitabevi, s. 101.

21 Güriz, s. 65.

22 Güriz, s. 67.

23 "Yüksek mahkemelerin oynaması gereken rol tam da yargı kararlarında doğabilecek içtihat farklılıklarına bir çözüm getirmektir.” AyM İkinci Bölüm: Selvi Ağgül ve Diğerleri Başvurusu/Başvuru No. 2013/6201, par. 61. Ayrıca bkz. AyM Birinci Bölüm: Semra Bekiroğlu ve Diğerler Başvurusu/Başvuru No. 2013/6717, par. 61; AyM Genel Kurul: Türkan Bal Başvurusu/Başvuru No. 2013/6932, par. 56.

24 AyM Birinci Bölüm: Mehmet Çelik Başvurusu(2)/Başvuru No. 2015/889, par. 62. 
Yüksek mahkemelerin kararları, mevzuatın açık olmayan noktalarını aydınlatabilir, boşlukları doldurabilir ve hukukun ülkenin her yerinde aynı şekilde uygulanması sağlar ${ }^{25}$. Bir yüksek mahkemenin daireleri, kurulları ve bunların birbiri arasında ve yüksek mahkemelerin de kendi aralarında bir içtihat birliği varsa kanunlar bütün yurtta eşit uygulanıyor demektir ${ }^{26}$. Buna karşın yüksek mahkemelerin, ilk derece mahkemelerinin içtihat farklılıklarını gidermek bir yana bizzat verdikleri kararlarla istikrarsızlığa yol açmaları, hukuki güvenlik ilkesiyle bağdaşmaz ${ }^{27}$.

Mahkeme kararlarında istikrar sağlanması önemli olduğu içindir ki Anayasa Mahkemesi bireysel başvuru yolunun kabul edilmesini müteakip artan iş yükü karşısında kararlarında istikrarı sağlamak için Araştırma ve İçtihat Birimi kurmuştur $^{28}$. Ayrıca yine idari ve adli yargı düzenlerinde bulunan içtihatları birleştirme müessesesi de içtihat birliği ve istikrarının sağlanmasını amaçlamaktadır.

Mahkeme kararlarında istikrar bulunmamasi ${ }^{29}$, hukuki güvenlik ilkesinin ihlaline neden olur ${ }^{30}$. Kişilerin yargı organlarına duymaları beklenen saygı

25 Kuru, Baki/Arslan, Ramazan/Yılmaz, Ejder (2011) Medeni Usul Hukuku, 22. Baskı, Ankara, Yetkin Yayınları, s. 67.

26 Kuru/Arslan/Yılmaz, s. 677.

27 Taşdelen, Okan "Çelişkili Yargı Kararlarının Adil Yargılanma Hakkı Bağlamında Değerlendirilmesi”, Uyuşmazlık Mahkemesi Dergisi, Y. 2016, S. 7, http:// dergipark.gov.tr/download/article-file/229930, s. 1018.

28 Anayasa Mahkemesi İçtüzügü'nün 3. maddesi uyarınca Araştırma ve İçtihat Birimi "Mahkeme kararlarını izleyerek içtihadın geliştirilmesi ve tanıtımı için çalışmalar yapmak, içtihat farklilıklarının önlenmesine yönelik önerilerde bulunmak ve bu amaçlarla istatistikler ve araştırma raporları hazırlamakla görevli birim"dir.

29 Kuru/Arslan/Yılmaz, s. 677; Aliefendioğlu, Ertan “İdari Yargıda İki Sorun”, Danıștay Dergisi, S: 113, s. 1-2; Taşdelen, s. 987

30 “... Benzer olaylar çerçevesinde verilen mahkeme kararlarında görülebilecek tutarsızlıklar, hukuki belirsizlik oluşturmaları nedeniyle Anayasa Mahkemesinin yapacağı incelemede dikkate alınacaktır." AyM Birinci Bölüm: Semra Bekiroğlu ve Diğerler Başvurusu/Başvuru No. 2013/6717, par. 68. Ayrıca bkz. AyM Genel Kurul: Türkan Bal Başvurusu/Başvuru No. 2013/6932, par. 63. 47. “... birden fazla içtihadın varlı̆̆ı, hukuk kurallarının temel bir özelliği olan bireyin davranışın yönlendirebilme gücünü zayıflatacak bir boyuta ulaşmışsa bireylerin hangi içtihada göre davranışlarını yönlendirecekleri belirsizleşeceğinden öngörülebilirlik ortadan kalkar (Mehmet Arif Madenci, \$ 84)" AyM İkinci Bölüm: Hasibe Uysal Başvurusu/Başvuru No. 2014/3975, par. 47. “...birden fazla içtihadın varlığı hukuk kurallarının temel bir özelliği olan, bireyin davranışını yönlendirebilme gücünü zayıflatacak bir boyuta ulaşmışsa kamu düzeninin bozulduğundan söz edilebilir. Bu durumda bireylerin hangi içtihada göre davranışlarını yönlendirecekleri belirsizleşeceğinden öngörülebilirlik ortadan kalkar.” AyM İkinci Bölüm: Mehmet Arif Madenci Başvurusu/Başvuru No. 2014/13916, par. 84. 
ve güveni zedeler ${ }^{31}$; adalet duygusunu incitir, yerine göre temelden sarsar; genellik, eşitlik ve adil yargılanma hakkıyla bağdaşmaz ${ }^{32}$.

\section{MAHKEME HANGİ HALLERDE BENZER KONUDA FARKLI BİR KARAR VEREBILLIR?}

Uyuşmazlıkların dayandıkları olaylar ve sorunlar farklıysa, farklı karar verilmesi normal ${ }^{33}$ hatta olması gerekendir ${ }^{34}$. Nitekim Anayasa Mahkemesi'ne göre içtihat farklılığından söz edilebilmek için ön koşul, dava konusu edilen uyuşmazlıkların, özü itibarıyla aynı mahiyette olmasıdır. Uyuşmazlıkların içeriğinin ve niteliğinin örtüşmediği, esaslı noktalarda ayrıldığ 1 durumlarda, verilen kararlar arasındaki farklılık, içtihat farklılığı olarak değerlendirilemez ${ }^{35}$.

31 “... Hukuk devletinin asli unsurları arasinda yer alan hukuki belirlilik veya güvenlik ilkesi ise hukuki durumlarda belirli bir istikrarı temin etmekte ve kamunun mahkemelere güvenine katkıda bulunmaktadır. Birbiriyle uyuşmayan mahkeme kararlarının sürüp gitmesi, yargı sistemine güveni azaltarak yargısal bir belirsizliğe yol açabilir (Nejdet Şahin ve Perihan Şahin/Türkiye [BD], B. No: 13279/05, 20/10/2011, \$57). ... Yargısal kararlardaki değişiklikler, hukukun dinamizmini ve mahkemelerin yaklaşımlarını yaşanan gelişmelere uyarlama kabiliyetlerini yansıtması yönüyle olumludur. Ancak uygulamada birliği să̆lamaları beklenen yüksek mahkemeler içinde yer alan dairelerin benzer davalarda tatmin edici bir gerekçe göstermeksizin farklı sonuçlara ulaşmaları, bir kararın belirli bir daireye düştüğü takdirde onanacağı, başka bir daire tarafindan ele alındiğı takdirde bozulacağı gibi ihtimale dayalı ve birbirine zit sonuçları ortaya çıkartır. Bu ise hukuki belirlilik ve öngörülebilirlik ilkelerine ters düşecektir. Ayrıca, böyle bir algının toplumda yerleşmesi hâlinde bireylerin yargı sistemine ve mahkeme kararlarına duymaları beklenen güven zarar görebilir.” AyM Birinci Bölüm: Semra Bekiroğlu ve Diğerler Başvurusu/Başvuru No. 2013/6717, par. 57 ve 69. Ayrıca bkz. AyM Genel Kurul: Türkan Bal Başvurusu/Başvuru No. 2013/6932, par. 64.

32 Anayasa Mahkemesine göre içtihat değişikliği sonucunu doğuran farklı değerlendirmenin hukuki güvenlik ve belirlilik ilkesi bağlamında hakkaniyete uygun yargılanma hakkı kapsamında değerlendirilmesi gerekir. AyM İkinci Bölüm: Ahmet Acar Başvurusu/ Başvuru No. 2014/19936, par. 45.

33 Taşdelen, s. 999.

34 "İhtilaf konusu davalardaki uyuşmazlıkların veya olayların birbirinden farklılık göstermesi, iki karardaki farklılaşan değerlendirmeleri haklı gösterir ve aynı konuda verilmiş çelişen hükümlerden bahsedilemez." AyM Birinci Bölüm: Ahmet Saygılı ve Şefika Saygılı Başvurusu/Başvuru No. 2013/135, par. 42. Ayrıca bkz. AyM Birinci Bölüm: Semra Bekiroğlu ve Diğerler Başvurusu/Başvuru No. 2013/6717, par. 62; AyM Genel Kurul: Türkan Bal Başvurusu/Başvuru No. 2013/6932, par. 57; AyM İkinci Bölüm: Ercan Din Başvurusu/Başvuru No. 2014/94, par. 51; AyM İkinci Bölüm: Murat Cihangiroğlu Başvurusu/Başvuru No. 2014/952, par. 41.

35 AyM İkinci Bölüm: Engin Selek Başvurusu/Başvuru No. 2015/19816, par. 54. 
Mahkeme benzer olaylarda farklı bir karar verme gereğini duyarsa, önceki kararından ayrılmaya icbar eden gerekçeleri belirtmelidir ${ }^{36}$. Bu gerekçeler; mevzuat değişikliği, sonraki olayın farklı somut özellikler taşıması, önceki kararın yanlış olması, koşulların değişmesi, kararın değişen şartlar nedeniyle adil olmaktan çıkması, toplumsal değişimin farklı karar vermeyi gerektirmesi ve kuralın yeni yoruma müsaade etmesi gibi çeşitlidir ${ }^{37}$. Ancak mahkemenin her durumda yapması gereken, benzer konuda farklı bir karar vereceği zaman bunun gerekçesini ortaya koymaktır.

Aynı maddi vakıaya ilişkin olarak mahkemelerin verdiği farklı kararlara istinaden Anayasa Mahkemesi'nin bireysel başvuru kararları üzerinde durulmalıdır. Zira örnek olayda Danıştay 10. Dairesi’nin birinci ve ikinci kararları aynı vakıaya (taşınmazın hangi idareye lazım geldiğine) ilişkindir. Anayasa Mahkemesi'ne ${ }^{38}$ göre “Uyuşmazlığın çözümünde etkili olan maddi vakıaların değerlendirilmesi, yorumlanması ve nitelendirilmesi derece mahkemelerinin takdirindedir. Maddi vakıalar, uyuşmazlıkta uygulanacak hukuk kurallarından farklı olarak sadece somut bir olayı ilgilendirdiğinden ancak somut olayın koşulları çerçevesinde yorumlanabilir ve anlamlandırılabilir. Somut olayın tek bir uyuşmazlı̆̆a konu edildiği durumlarda maddi vakıalara ilişkin olarak mahkemeler arasında görüş ayrılı̆̆ı oluşması mümkün değildir. Buna mukabil aynı olay çerçevesinde birden fazla uyuşmazlı̆̆ın birden fazla mahkemede görüldüğ̈̈ hallerde farklı mahkemelerin aynı olay kapsamındaki bir maddi vakıaı

36 İçtihadın bağlayıcılığının kural; içtihattan ayrılmanın ise istisnai olduğu da ifade edilmektedir. Kayhan'a göre Hiç bir mahkeme, benzer konuda daha önce verilmiş bir kararı yok sayamaz; aksi hal pratikte hukuk düzeninin ve mahkemenin kendisini yok sayması anlamına gelir. Kayhan, s. 346 ve 354. Ayrıca bkz. Önen, Ergun (1968) “Özel Olarak Kazai İçtihadın Tanzim Edici (Normatif) Kuvveti Meselesi”, Ankara Üniversitesi Hukuk Fakültesi Dergisi, C: 25, S: 1, s. 165; Köküsarı, s. 116.

37 "Aynı hukuki metne ilişkin olarak aynı derecedeki bağımsız yargı mercileri arasındaki yorum ve içtihat farklılıkları ile temyiz mercilerinin uyuşmazlıklara ilişkin olarak tarafların talepleri ve delilleri arasındaki yorum farklilıkları, tek başına adil yargılanma hakkının ihlali niteliğinde kabul edilemeyeceği gibi (Ahmet Sağlam, B. No: 2013/3351, 17/9/2013, \$ 45) Mahkemelerce hukuk kurallarının yorumlanması ve delillerin değerlendirilmesinde farklılılar meydana gelmesi ya da önceki çözümün tatminkar bulunmaması, yeni kabul edilmiş bir yasanın yorumlanmasında içtihadın müstakar olması için belli bir zamana ihtiyaç duyulması gibi çeşitli nedenlerle içtihat değişikliğine gidilmesi de tek başına adil yargılanma hakkının ihlali niteliğinde kabul edilemez." AyM İkinci Bölüm: Selvi Ağgül ve Diğerleri Başvurusu/Başvuru No. 2013/6201, par. 64.

38 AyM İkinci Bölüm: Özlem Terzioğlu Başvurusu/Başvuru No. 2014/19341, par. 45, 46, 52 ve 53. 
farklı değerlendirmesi ve yorumlaması mümkündür. Maddi vakıanın farklı yorumlanmasına bağlı olarak aynı olaya ilişkin uyuşmazlıklarda farklı sonuçlara ulaşılması ve birbiriyle çelişen kararlar verilmesi olasıdır. Bu durumda da aynı maddi vakıanın farklı değerlendirilmesine bağh olarak adil yargılanma hakkının ihlal edilmesi söz konusu olabilir. Mahkemelerin maddi olgularla ilgili değerlendirme ve nitelemeleri ile mutlak bir şekilde bağlı olmaları söz konusu olmayı bunları değiştirmeleri de mümkündür. Ancak maddi olgularla ilgili değerlendirmelerin ayn olay kapsamındaki diğer uyuşmazlıklar yönünden kuvvetli delil teşkil edebileceği gözetildiğinde mahkemelerin daha önce ulaştıklarından farklı bir sonuca ulaşmaları durumunda bunun gerekçesini ikna edici bir şekilde ortaya koymaları beklenir. ... Bu bağlamda Dairenin daha önceki kararında iki Şirket arasında cereyan eden ilişkiyi (maddi vakıayı) şube devri olarak nitelediği halde başvurucu tarafindan açılan bu davada şube devrinin söz konusu olmadiğı kanaatine varan Mahkeme kararını onamış olması, Daireyi bu görüş değişikliği için tatmin edici bir gerekçe açıklama yükümlülü̈̆̈̈ altına sokmaktadır. Oysa Dairenin onama kararında herhangi bir gerekçeye yer vermediği görülmektedir. Sonuç olarak Dairenin aynı maddi vakıaya ilişkin olarak önceki kararlarında ulaştı̆̆ı kanaatin aksi yöndeki Mahkeme kararını herhangi bir gerekçe açıklamadan onamasının, başvurucunun açtığı davanın görülmesi bakımından hukuki belirsizliğe neden olduğu ve başvurucu açısından öngörülemez bulunduğu sonucuna varılmıştır."

\section{HUKUKİ GÜVENLİK İLKESİ BAĞLAMINDA YARGI KARAR- LARINDA İSTIKRAR}

Yasama, yürütme (idare) ve yargı erklerine çeşitli yükümlülükler getiren; "belirlilik", "istikrar” ve “öngörülebilirlik" alt ilkelerinden oluşan hukuki güvenlik ilkesi hukuk devletinin ön koşullarındandır.

Hukuki güvenlik, kişilerin devlete güven duymasını ve bu güvenin muhafazasını sağlar; sonraki kararların kabulünü kolaylaştırır ve toplumsal huzuru arttırır. Kişilerin bağımsız biçimde karar alabilmelerini ve uygulayabilmelerini mümkün kılar ${ }^{39}$.

Anayasa Mahkemesi'ne göre "0 "Kişilerin hukuki güvenliğini sağlamayı amaçlayan hukuki güvenlik ilkesi, hukuk normlarının öngörülebilir olmasını, bi-

\footnotetext{
39 Köküsarı, s. 190 vd.

40 AyM: 23.12.2015, E. 2015/15, K. 2015/118.
} 
reylerin tüm eylem ve işlemlerinde Devlete güven duyabilmesini, Devletin de yasal düzenlemelerinde bu güven duygusunu zedeleyici yöntemlerden kaçınmasını gerekli kılar. Belirlilik ilkesi ise yalnızca yasal belirliliği değil, daha geniş anlamda hukuki belirliliği ifade etmektedir. Yasal düzenlemeye dayanarak erişilebilir, bilinebilir ve öngörülebilir gibi niteliksel gereklilikleri karşılaması koşuluyla, mahkeme içtihatları ve yürütmenin düzenleyici işlemleri ile de hukuki belirlilik săglanabilir. Hukuki belirlilik ilkesinde asıl olan, bir hukuk normunun uygulanmasıyla ortaya çıkacak sonuçların o hukuk düzeninde öngörülebilir olmasıdır." $\mathrm{Bu}$ karardan da anlaşılacağı üzere belirliliğin ve dolayısıyla hukuki güvenliğin sağlanması diğer hususların yanında mahkeme kararlarının da benzer olaylarda istikrarlı bir biçimde aynı yönde olmasına bağlıdır ${ }^{41}$.

Yargı kararlarında istikrar, istikrarın hukuki güvenlik ve adil yargılanma hakkı ile ilişkisi Anayasa Mahkemesi'nin bireysel başvuru kararlarında çokça tartışılmıştır. Anayasa Mahkemesi Avrupa İnsan Hakları Mahkemesi kararlarından da yararlanmak suretiyle yargısal düzeyde ve mahkeme düzeyinde içtihat istikrarının sağlanmasına yönelik olarak şu yönde karar vermektedir" ${ }^{42}$ : "Kural olarak, aynı derecedeki bağımsız yargı mercileri arasında, aynı hukuki metne ilişkin yorum ve içtihat farklılıkları tek başına adil yargılanma hakkının ihlali niteliğinde kabul edilemeyeceği gibi, temyiz mercilerinin, uyuşmazliklara ilişkin olarak tarafların talepleri ve delilleri arasındaki yorum farklılıkları da tek başına adil yargilanma hakkının ihlali niteliğinde kabul edilemez. Bu durumun farklı yargı kolları açısından da geçerli olduğunun kabulü gerekir. Bu kapsamda farklı kararların aynı mahkemeden çıkmış olması da tek başına, adil yargılanma hakkının ihlali anlamına gelmeyecektir. Değiş̧ik yönlerde kararlar verilmesi ihtimali, Yargıtay, Danıştay, Askeri Yüksek İdare Mahkemesi gibi çeşitli yüksek mahkemelerden oluşan yargı sistemimizin kaçınılmaz bir özelliği olarak kabul edilmelidir. Dolayısıyla, bireylerin makul güvenlerinin korunması ve hukuki güvenlik ilkesi, içtihadın değişmezliği şeklinde bir hak bahşetmemektedir. Mahke-

41 Anayasa Mahkemesi bir başka kararında yargıdaki istikrarın bozulmasını, hukuk devleti ilkesine aykırılık olarak değerlendirmektedir. AyM: 17.05.2007, E. 2004/13, K. 2007/58.

42 AyM Birinci Bölüm: Ahmet Saygılı ve Şefika Saygılı Başvurusu/Başvuru No. 2013/135, par. 37, 38, 39, 40, 41 ve 45. Ayrıca bkz. AyM Birinci Bölüm: Semra Bekiroğlu ve Diğerler Başvurusu/Başvuru No. 2013/6717, par. 58, 59, 60 ve 69; AyM Genel Kurulu: Türkan Bal Başvurusu/Başvuru No. 2013/6932, par. 53, 54, 55; AyM İkinci Bölüm: Murat Cihangiroğlu Başvurusu/Başvuru No. 2014/952, par. 38, 40. 
melerin yorumlarında dinamik ve evirilen bir yaklaşımın sürdürülememesi reform ya da gelişimi engelleyeceğinden, kararlardaki değişim, adaletin iyi idaresine aykırılık teşkil etmez. Mahkeme içtihatlarındaki değişme yargı organlarının takdir yetkisi kapsamında kalmakta olup, böyle bir değişiklik özü itibarıyla, önceki çözümün tatminkâr bulunmaması anlamına gelir. Ancak, aynı hususta daha önce çıkan kararlardan farklı bir hüküm kurulması halinde, mahkemelerce, bu farklılaşmaya ilişkin makul bir açıklama getirilmesi gerekmektedir. ... Yargisal kararlardaki değişiklikler, hukukun dinamizmini ve mahkemelerin yaklaşımlarını yaşanan gelişmelere uyarlama kabiliyetlerini yansıtması yönüyle olumludur. Ancak, uygulamadaki birlikteliği sağlamaları beklenen yüksek mahkemeler içinde yer alan dairelerin ya da farkl yargı kollarına ait mahkemelerin benzer davalarda tatmin edici bir gerekçe göstermeksizin farklı sonuçlara ulaşmalarının, bir kararın belirli bir daireye ya da farklı yargı koluna düştüğ̈̈ takdirde onanacağı veya olumlu neticeleneceği, başka bir daire tarafından ele alındığı takdirde bozulacağı veya olumsuz neticeleneceği gibi birbirine zit sonuçların ortaya çıkma beklentisinin, hukuki belirlilik ve öngörülebilirlik ilkelerine aykırı olduğu açıktır. Ayrıca, böyle bir algının toplumda yerleşmesi halinde, bireylerin yargı sistemine ve mahkeme kararlarına duymaları beklenen güven zarar görebilir." Yine Anayasa Mahkemesine göre ${ }^{43}$ : “... farklı kararların aynı mahkemeden çıkmış olması tek başına, adil yargılanma hakkının ihlali anlamına gelmeyecektir. ... Yazılı hukuk sistemine tabi ülkelerde içtihat değişmez bir olgu olmadiğından mahkeme içtihatlarındaki değişme yargı organlarının takdir yetkisi kapsamında kalmaktadır. Böyle bir değişiklik özü itibarıla önceki çözümün tatminkar bulunmaması anlamına gelmektedir (S.S. Balıklıçeşme Beldesi Tarım Kalkınma Kooperatifi ve diğerleri/Türkiye, B. No: 3573/05 ... , 30/11/2010, \$28). Ancak aynı hususta daha önce çıan kararlardan farklı bir hüküm kurulması halinde mahkemelerce bu farklılaşmaya ilişkin makul bir açıklama getirilmesi gerekmektedir."

Anayasa Mahkemesi'nin yukarıdaki karalarından anlaşılacağı üzere bir mahkeme benzer konuda farklı bir karar vereceği zaman, bunun gerekçesini ortaya koymalıdır". Anayasa Mahkemesi "gerekçe" ile ilgili olarak ise şunları

\footnotetext{
43 AyM İkinci Bölüm: Selvi Ağgül ve Diğerleri Başvurusu/Başvuru No. 2013/6201, par. 55 ve 62.

44 "Uygulamadaki birlikteliği sağlamaları beklenen yüksek mahkemeler içinde yer alan dairelerin benzer davalarda tatmin edici bir gerekçe göstererek farklı sonuçlara ulaşmaları, hukuki belirlilik ve öngörülebilirlik ilkeleri çerçevesinde, verilen kararların ihtimale dayalı sonuçlar olmamasını ve birbirine zıt ilamların ortaya çıkmamasını gerektirir.” AYM Birinci Bölüm: Genco Acar Başvurusu/Başvuru No. 2013/7938, par. 62.
} 
söylemektedir" ${ }^{45}$ : "Anayasanın 141. maddesinde güvence altına alınan gerekçeli karar hakkı, mahkeme kararlarında kararların dayandığı hukuki gerekçenin yeterli açıklıkta gösterilmesini gerektirir. Bununla birlikte mahkeme kararlarının gerekçesinde tarafların tüm iddialarının ayrıntılı bir biçimde tartışılması zorunluluğu bulunmamaktadır. Gerekçenin ayrıntısı davanın niteliğine göre değişmekle birlikte kararın hüküm kısmına dayanak oluşturacak hukuki bir gerekçenin kısa ve özet de olsa bulunmasının zorunlu olduğu açıktır. Kararların gerekçeli olması, davanın taraflarının mahkeme kararının dayanağını öğrenerek mahkemelere ve genel olarak yargıya güven duymalarını sağladığı gibi, tarafların kanun yoluna etkili başvuru yapmalarını mümkün hale getiren en önemli faktörlerdendir. Gerekçesi bilinmeyen bir karara karşı gidilecek kanun yolunun etkin kullanılması mümkün olmayacağı gibi bahsedilen kanun yolunda yapılacak incelemenin de etkin olması beklenemez." "Tarafsızlı̆gı, keyfiliği, denetimden kaçmay ve perdelemeyi önlemek için mahkemeler, kararın verilmesine neden olan temelleri yeterince açık olarak belirtmekle yükümlüdürler. Mahkemelerin yargllama süresince kendilerine iletilen her iddia ve talebi gözetme zorunda olmadıkları biçimindeki serbesti, kararın verilmesine neden olan temellere asgari açıklıkta değinilmesi görevini ortadan kaldıracak şekilde yorumlanamaz." ${ }^{\text {"46 }}$

Anayasa Mahkemesi'ne göre mahkemelerin, başvurucuların önemli bazı iddialarına yanıt vermemiş olması, kişinin iddialarının incelenmesi hakkının

45 AyM İkinci Bölüm: Vesim Parlak Başvurusu/Başvuru No. 2012/1034, par. 33 ve 34. Yine Anayasa Mahkemesi'ne göre "Mahkeme kararlarının gerekçeli olması adil yargılanma hakkının unsurlarından birisi olmakla beraber, bu hak yargılamada ileri sürülen her türlü iddia ve savunmaya ayrıntıl ş̧ekilde yanıt verilmesi şeklinde anlaşılamaz. Bu nedenle, gerekçe gösterme zorunluluğunun kapsamı kararın niteliğine göre değişebilir. Bununla birlikte başvurucunun ayrı ve açık bir yanıt verilmesini gerektiren usul veya esasa dair iddialarının cevapsız bırakılmış olması bir hak ihlaline neden olacaktır. Bunun yanı sira, kanun yolu mahkemelerince verilen karar gerekçelerinin ayrıntılı olmaması da bu hakkın ihlal edildiği şeklinde yorumlanmamalıdır. Kanun yolu mahkemelerince verilen bu tür kararların, ilk derece mahkemesi kararlarında yer verilen gerekçelerin kabul edilmiş olduğu şeklinde yorumlanması uygun olup, bu husus AİHM içtihadında da, üst dereceli mahkeme tarafindan benimseme yöntemiyle önceki mahkeme kararının gerekçesinin özümsenmesi şeklinde yorumlanmaktadır.” AyM İkinci Bölüm: Muhittin Kaya Ve Muhittin Kaya İnşaat Taahhüt Madencilik Gıda Turizm Pazarlama Sanayi Ve Ticaret Ltd. Şti. Başvurusu/Başvuru No. 2013/1213, par. 26. Ayrıca bkz. AyM Birinci Bölüm: İbrahim Ataş Başvurusu/Başvuru No. 2013/1235, par. 23, 24 ve 25.

AyM Genel Kurul: Sencer Başat ve Diğerleri Başvurusu/Başvuru No. 2013/7800, par. 58. 
yanında, adil yargılanma hakkının önemli gerekliliklerinden biri olan mahkemelerin kararı gerekçelendirme yükümlülüğü ile de ilişkilidir. Zira bir muhakemede usule ilişkin koruma sağlayan adil yargılanma hakkının önemli unsurlarından biri olan gerekçeli karar hakkı da kişilerin adil bir şekilde yargılanmalarını sağlamayı ve denetlemeyi amaçlamaktadır. Bu bağlamda mahkemeler, kararlarını hangi temele dayandırdıklarını yeterince açık olarak belirtme yükümlülügü altında olup bu yükümlülük, tarafların temyiz hakkını kullanabilmeleri için gerekli olmasının yanı sıra, muhakeme sırasında ileri sürdükleri iddialarının kurallara uygun bir biçimde incelenip incelenmediğini bilmeleri ve ayrıca demokratik bir toplumda, toplumun kendi adına verilen yargı kararlarının sebeplerini öğrenmelerinin sağlanması için de gereklidir ${ }^{47}$. Anayasa Mahkemesi'nin de belirttiği üzere mahkemelerin "ileri sürülen iddia ve savunmalara şeklen cevap vermiş olmaları yeterli olmayıp, iddia ve savunmalara verilen cevapların dayanaksız olmaması, mantıklı ve tutarlı olması da gerekir. Diğer bir ifadeyle mahkemelerce belirtilen gerekçeler, davanın şartları dikkate alındığında makul olmalıdır. Makul gerekçe, davaya konu olay ve olguların mahkemece nasıl nitelendirildiğini, kurulan hükmün hangi nedenlere ve hukuksal düzenlemelere dayandırıldığını ortaya koyacak, olay ve olgular ile hüküm arasındaki bağlantıyı gösterecek nitelikte olmalıdır (bkz. B. No: 2013/1235, 13/6/2013, \$24). Gerekçelendirme, davanın sonucuna etkili olay, olgu ve argümanları açıklamak yükümlülüğ̈̈ olmakla birlikte, bu şekildeki gerekçelendirmenin mutlaka detaylı olması şart değildir. Ancak gerekçelendirmenin, iddia ve savunmadan birinin diğerine üstün tutulma sebebinin ve bu kapsamda davanın taraflarınca gösterilen delillerden karara dayanak olarak alınanların mahkemelerce kabul edilme ve diğerlerinin reddedilmesi hususunda, makul dayanakları olan bir bilgilendirmeyi sağlayacak ölçü ve özene sahip olması gerekmektedir. Zira bir davada tarafların, hukuk düzenince hangi nedenle haklı veya haksız görüldüklerini anlayı değerlendirebilmeleri için usulüne uygun şekilde oluşturulmuş, hükmün içerik ve kapsamı ile bu hükme varılırken mahkemenin neleri dikkate aldığı ya da almadı̆̆ın gösteren, ifadeleri özenle seçilmiş ve kuşkuya yer vermeyecek açıklıktaki bir ge-

47 AyM Genel Kurul: Sencer Başat ve Diğerleri Başvurusu/Başvuru No. 2013/7800, par. 31 ve 34 . 
rekçe bölümünün ve buna uyumlu hüküm fikralarının bulunması "gerekçeli karar hakkı" yönünden zorunludur. Aksi bir tutumla, mahkemenin, davanın sonucuna etkili olduğunu kabul ettiği bir husus hakkında "ilgili ve yeterli bir yant" vermemesi veya yant verilmesini gerektiren usul veya esasa dair iddialarin cevapsız bırakılmış olması bir hak ihlaline neden olabilecektir." ${ }^{38}$

Mahkemelerin gerekçelendirme yükümlülüğü “yargılamada ileri sürülen her türlü iddia ve savunmaya, karar gerekçesinde ayrıntıl şekilde yanıt verilmesi şeklinde anlaşılamaz (bkz. B. No: 2013/1213, 4/12/2013, \$ 26). Bu nedenle, bir kararda tam olarak hangi unsurların bulunması gerektiği, davanın niteliğine ve koşullarına bağlıdır. Bununla birlikte muhakeme sırasında açık ve somut bir biçimde öne sürülen iddia ve savunmaların davanın sonucuna etkili olmasl, başka bir deyişle davanın sonucunu değiştirebilecek nitelikte bulunması halinde, davayla doğrudan ilgili olan bu hususlara mahkemelerce makul bir gerekçe ile yanıt verilmesi gerekir." ${ }^{39}$ Yine Anayasa Mahkemesine göre ${ }^{50}$ "İtiraz veya temyiz merciinin, itiraz veya temyiz incelemesine konu mahkeme kararına ve bu karardaki gerekçelere katıldı̆̆ı durumlarda, buna ilişkin kararını ayrıntılı olarak gerekçelendirmemesi, kural olarak, gerekçeli karar hakkına ve dolayısıyla adil yargılanma hakkına aykırılık teşkil etmez."

\section{SONUÇ : ÖRNEK OLAYDAKİ DANIŞTAY KARARLARININ DEĞER- LENDIRILMESİ}

Taşınmaza hangi idarenin daha fazla ihtiyacı olduğu veya ikinci tahsis işleminin mahkeme kararını etkisiz hale getirmeyi amaçlayıp amaçlamadığı sorularına cevap vermek, bu makalenin konusu dışındadır. Burada, Danıştay 10.

48 AyM Genel Kurul: Sencer Başat ve Diğerleri Başvurusu/Başvuru No. 2013/7800, par. 36, 37, 38 ve 39.

49 AyM Genel Kurul: Sencer Başat ve Diğerleri Başvurusu/Başvuru No. 2013/7800, par. 35.

50 AyM Birinci Bölüm: Lokman Sapan Başvurusu/ Başvuru Numarası: 2013/723, par. 44. Ayrıca bkz. “... temyiz mercilerinin kararlarının tamamen gerekçeli olması zorunlu değildir. Temyiz merciinin yargılamayı yapan mahkemenin kararıla aynı fikirde olması ve bunu ya aynı gerekçeyi kullanarak ya da basit bir atıfla kararına yansıtması yeterlidir. Burada önemli olan husus, temyiz merciinin bir şekilde temyizde dile getirilmiş ana unsurları incelediğini, derece mahkemesinin kararın inceleyerek onadığını ya da bozduğunu göstermesidir.” AyM İkinci Bölüm: Ahmet Sağlam Başvurusu/ Başvuru No. 2013/3351, par. 50. 
Dairesinin seçilen iki kararı, Anayasa Mahkemesi'nin bireysel başvuru kararlarında mahkeme kararlarında istikrar ve gerekçe ile ilgili olarak belirttiği görüşler doğrultusunda değerlendirilecektir.

Davaların konuları II numaralı başlık altında da belirtildiği gibi Üniversite adına yapılan tahsisin kaldırılması ve Bakanlık adına tahsis kararı alınmasıdır. Diğer bir deyişle iki davanın konusu ve tarafları aynıdır. Danıştay ilk tahsis işlemi iptal edilirken "Bakılan uyuşmazlıkta, Davacı Üniversiteye tahsisi yapılan taşınmazın konumu itibariyle Üniversitenin merkez kampüsü ile diğer fakültelerinin yoğun olarak bulunduğu alanda yer aldiğl, eğitim hizmetlerinin birlikte yürütülmesi isteğinden hareketle söz konusu taşınmaza anılan Üniversitenin ihtiyacının bulunduğu ve bu bağlamda Üniversiteye yapılan tahsis amacının ortadan kalkmadığ ve bu amaca yönelik hizmetin gerçekleştirilmesinin ise olanaklı olduğu açıkça görülmektedir." gerekçesine dayandıktan sonra ikinci tahsis işleminin iptali için açılan davada ilk derece mahkemesinin verdiği red kararında yer alan "dava konusu taşınmazın 1962 yılından bu yana halen Milli Ĕ̆itim Bakanlı̆̆ uhdesinde olduğu, Gazi Üniversitesi Rektörlüğünün, 1990 yılında, yüksek öğretmen okulu olarak kullanılmak üzere kendisine tahsis edilen taşınmazı fiilen kullanmadığı, söz konusu taşınmaza Milli Eğitim Bakanlığının ihtiyacının bulunduğu, bu hususun yapılan tespitle de sabit olduğu, bu bağlamda Üniversiteye yapılan tahsis amacının ortadan kalktığı" gerekçesini uygun bulmuştur.

Anılan iki karar arasında ilk karardan ayrılmayı haklı gösterecek herhangi bir neden bulunmadığı gibi ikinci karar aşamasında Valiliğe yaptırılan tespit ilk kararın alınma gerekçesinin dışında yeni bir şey söylememektedir. İlk kararın alınması aşamasında olduğu gibi ikinci karar alınırken de taşınmaz Bakanlık tarafından kullanılmakta ve Üniversite tarafından kullanılamamaktadır. Diğer bir ifadeyle iki yargı kararı arasında farklılaşmayı gerektiren herhangi bir gelişme olmamış; Bakanlık taşınmazı tahsis kararına rağmen fiilen kullanmaya devam etmiş, Üniversite taşınmazın bulunduğu mahalden taşınmamış ve Üniversitenin anılan taşınmaza ihtiyacı devam etmiştir. Anayasa Mahkemesi’ne göre somut olayın gerçekleşme koşullarına ilişkin kabul bakımından ortaya çıkan farklılıklar, aynı olaya ilişkin kararlar arasında bulunan farklılıklar, hukuki belirsizliğe neden olur, öngörülemezdir ve bu nedenlerden ötürü de adil yarg1lanma hakkının ihlaline neden olur ${ }^{51}$.

51 AyM İkinci Bölüm: Ercan Din Başvurusu/Başvuru No. 2014/94, par. 62, 65 ve 66. 
Anayasa Mahkemesi benzer konularda farklı içtihatların farklı yargı düzenlerinden çıkmasının dahi olumsuz sonuçları olabileceğini ve yüksek mahkemelerin, böyle bir olumsuz sonucun bizatihi kaynağı olmamak adına farklı uygulamaları ortadan kaldırmaya yönelik gerekli özeni göstermeleri gerektiğini ifade ederken ${ }^{52}$ içtihat mahkemesi olan Yüksek Mahkemenin aynı Dairesinin aynı konuda hakkın yerine getirilmesine engel nitelikte karar vermesi evleviyetle olumsuz sonuçlar doğmasına neden olabilecektir.

Anayasa Mahkemesi’nin istikrarlı bir biçimde vurguladığı gibi mahkemeler benzer olaylarda farklı kararlar verebilir. Ancak mahkemelerin bire bir aynı olaylarda farklı kararlar verme konusunda takdir yetkilerinin daha sınırlı olması gerektiği ve dahası bunun da doyurucu bir gerekçeyle desteklenmesi gerektiği aşikardır. Yine Anayasa Mahkemesi'nin içtihatlarına göre ilk derece mahkemelerinin kararlarında taraflarca ileri sürülen bütün iddiaları karşılamaları gerekli olmadığı gibi temyiz mercilerinin de ilk derece mahkemesinin kararına katıldığını beyan etmesi kural olarak yeterlidir. Ancak örnek olay konusu edilen ilk derece mahkemeleri ve Danıştay kararlarında ilk karardan ayrılmayı gerektirecek bir değişiklik olmadığı ve mahkeme kararlarını etkisiz kılmaya yönelik işlem tesis edildiği iddiaları ikinci tahsis işlemi aleyhine açılan davalarda ve temyiz aşamasında karşılanmamıştır. Bu durumun hukuki güvenlik ilkesine ve bu bağlamda adil yargılanma hakkına aykırılık teşkil ettiği düşünülmektedir.

52 AyM İkinci Bölüm: Engin Selek Başvurusu/Başvuru No. 2015/19816, par. 59. 


\section{KAYNAKÇA}

Akyılmaz, Bahtiyar/Sezginer, Murat/Kaya, Cemil (2019) Türk İdare Hukuku, 10. Baskı, Ankara, Savaş Yayınevi.

Aliefendioğlu, Ertan “İdari Yargıda İki Sorun”, Danıştay Dergisi, S: 113, s. 1-20.

Bilge, Necip (2010) Hukuk Başlangıcı, 28. Bası, Ankara, Turhan Kitabevi.

Duran, Lütfi "Yüksek Mahkemeler Arasında İçtihat Uyuşmazlı̆̆ı", Mukayeseli Hukuk Araştırmaları Dergisi, Cezaevi Matbaası, İstanbul 1967, http://dergipark.gov.tr/download/article-file/ 14133.

Giritli, İsmet/Bilgen, Pertev/Akgüner, Tayfun/Berk, Kahraman (2013) İdare Hukuku, İstanbul, Der Yayınları.

Gözübüyük, Şeref/Tan, Turgut (2013) İdare Hukuku Cilt I Genel Esaslar, 9. Bası, Ankara, Turhan Kitabevi.

Günday, Metin (2013) İdare Hukuku, 10. Baskı, Ankara.

Güriz, Adnan (2003) Hukuk Başlangıcı, 9. Baskı, Ankara, Siyasal Kitabevi.

Kayhan, Fahrettin (1999) "Özel Hukuk Uygulamasında Yargı İçtihatlarının ve İçtihadı Birleştirme Kararlarının Normatif Gücü”, Türkiye Barolar Birliği Dergisi, S: 2, s. 341-363.

Köküsarı, İsmail (2015) Anayasa Hukukunda Hukuki Güvenlik İlkesi, Ankara, Adalet Yayınevi.

Kuru, Baki/Arslan, Ramazan/Yılmaz, Ejder (2011) Medeni Usul Hukuku, 22. Baskı, Ankara, Yetkin Yayınları.

Önen, Ergun (1968) “Özel Olarak Kazai İçtihadın Tanzim Edici (Normatif) Kuvveti Meselesi”, Ankara Üniversitesi Hukuk Fakültesi Dergisi, C: 25, S: 1 , s. 53-172.

Taşdelen, Okan "Çelişkili Yargı Kararlarının Adil Yargılanma Hakkı Bağlamında Değerlendirilmesi”, Uyuşmazlık Mahkemesi Dergisi, Y. 2016, S. 7, http:// dergipark.gov.tr/download/article-file/229930 